\title{
THE OPERATIVE PROFIT MARGIN AND INTEREST COST IN RETAIL FOOD
}

\author{
Dragana Vojteski Kljenak ${ }^{1}$, Radojko Lukic ${ }^{2}$, Gordana Gavric ${ }^{3}$, Milan Gavrilovic ${ }^{4}$ \\ *Corresponding authorE-mail:vojteski@live.co.uk
}

A R T I C L E I N F O
Review Article
Received: 04 August 2019
Accepted: 13 September 2019
doi:10.5937/ekoPolj1903799V
UDC 631.2:[330.143+336.78

Keywords:

net profit, interest, tax, depreciation, amortization

JEL: L81, M31, M41, O32

\section{A B S T R A C T}

Under the influence of different factors, the dynamics of the size of the operating profit margin of food trading companies in Serbia varies from comparable global food retailers in various countries. Based on the obtained results of empirical research, we can also conclude that the operating profit margin of the leading food trading companies in Serbia is lower than the in analyzed comparable food retail trade companies from the developed market economies. It points to the conclusion that it is necessary to efficiently manage revenues, costs, profit, assets, and financial structure in order to improve the performance of food trading companies in Serbia in the future. In order to increase the operating profit margin, as a measure of long-term performance, it is necessary to manage the financial structure of the food trading companies in Serbia as effectively as possible. The main objective of this paper is to apply dynamics of size and structure of operating margin of global retailers in Serbia by applying accounting methodology based on data from annual financial statements. It is an increasingly significant non-standard indicator of their performance. Therefore, this indicator will receive increasing attention in the future.

(C) 2019 EA. All rights reserved.

1 Dragana Vojteski Kljenak, Ph.D., Associate Professor, Faculty of Business Economics and Entrepreneurship, Mitropolita Petra 8, Belgrade, Republic of Serbia, Phone: +381 112762 194, E-mail: vojteski@live.co.uk, ORCID ID https://orcid.org/0000-0002-5707-1585

2 Radojko Lukic, Ph.D., Full Professor,University of Belgrade Faculty of Economics, Kamenica 6, Belgrade Republic of Serbia, Phone: +381 113021 112, E-mail: rlukic@ekof. bg.ac.rs ,ORCID ID https://orcid.org/0000-0001-6529-0297

3 Gordana Gavric, Ph.D., Assistant Professor, Faculty of Business Economics and Entrepreneurship, Mitropolita Petra 8,Belgrade, Republic of Serbia, Phone: +381 112762 194, E-mail: gordana.gavric.bg@gmail.com, ORCID ID https://orcid.org/0000-0002-0607-1075

4 Milan Gavrilovic, Ph.D., Assistant Professor, Faculty of Business Economics and Entrepreneurship, Mitropolita Petra 8, Belgrade, Republic of Serbia, Phone: +381 112762 194, E-mail: gavrilovicmilan82@gmail.com ORCID ID https://orcid.org/0000-0002-0130-6496 


\section{Introduction}

Considerable theoretical and practical attention has been paid in recent years to analyzing the operating profit margin or earnings before interest, taxes, depreciation and amortization (EBITDA margin) as a measure of the long-term performance of companies. On the basis of it, special indicators of long-term performance of companies have been developed. They are comparatively analyzed by individual companies (from the same and different sectors) and based on this -their long-term business success is recognized. Bearing this in mind, the subject of research in this paper is a comparative analysis of the operational profit margin of food retail enterprises in Serbia and comparable foreign retailers.

The aim of this research is to thoroughly investigate the problems of the operating profit margin as one of the determinants of the long-term performance of food trading companies in Serbia and, on that basis, to propose the measures for its improvement in the future. This gap is to a certain extent filled with this paper, in what we find its scientific and professional contribution.

The basic hypothesis of research in this paper is that the operating profit margin is a significant measure and determinant of the long-term performance of food trading companies. For these reasons it is necessary to investigate it more extensively on the example of food trade companies in Serbia, particularly the dynamics and factors of its size.

In this paper, we will explore the dynamics of the size of EBITDA margin of wellknown global food retailers, such as Wal-Mart, Tesco and Ahold Delhaize, in order to make comparisons of the EBITDA margin with Serbian trading companies. This provides the basis for proposing adequate measures to increase the size of the EBITDA margin, as a measure of long-term performance of food trading companies in Serbia. The EBITDA margin of the analyzed leading food trading companies in Serbia (Ahold Delhaize Serbia, Mercator-S and IDEA) is lower than that of analyzed comparable food retail companies from the developed market economies.

Overall, more efficient management of the financial structure of capital, sales revenues, costs of goods sold (including operating costs, interest) and profit can significantly influence the increase in the EBITDA margin as a measure of the long-term performance of food trading companies in Serbia. This will definitely have a positive impact on the dynamics of the size and efficiency of investments, as a key factor in the performance of food trade companies in Serbia.

Interest costs are a component of operational costs of trading companies (Popović, 2018). They are covered from the margin. Their size varies depending on the interest rate, foreign exchange rate, investment management efficiency, financial indebtedness, sales and other controlled and uncontrolled determinants ( Tao, 2019; Kenchington, 2019; Lambrinoudakis, 2019; Shamshur, 2019; Ye, 2019). This paper examines the dynamics and factors of the size of the costs of interest rates of food retail companies in Serbia for the period 2014 - 2017. The empirical results of the research show a con- 
tinuous reduction of the interest costs in the last years of the analyzed period. This had a positive effect on the performance of retail companies in Serbia.

\section{Materials and methods}

For the needs of the research of the treated problems in this paper, empirical data from the Agency for Business Registers of the Republic of Serbia were used. They are completely comparable to the same type of other global food retailers 'data and, in this sense, there are almost no restrictions on the obtained research results in this paper due to the fact that we used empirical data from their publicly disclosed financial statements in this study. With the defined aim and research hypothesis, the basic methodology in this paper is the comparative analysis and application of the relevant statistical analysis. Also, to a certain extent, the historical and normative methodology was applied in researching the treated problem in this paper. The operating profit margin or earnings before interest, taxes, depreciation and amortization (EBITDA margin) as a measure of performance has been used since the mid-1980s, especially since the 1990s in all companies, including wholesale and retail (Lukic, 11; Levy, 2019; Lekić et al., 2018; Lukić et al., 2018).

There is extensive literature written on the subject of general problem of measuring the significance of gross operating margin in financial reporting for the needs of more efficient company management (Sui, 2017). However, a number of published papers dedicated to the specificities of gross operating margin analysis in commercial enterprises (food retailers) is significantly lower (Berman, 2018; Levy, 2019; Corona, 2014; Špička, 2016; Tan, 2016; Calva, 2017; Carstea et al, 2017; Ko et al., 2017; Hoe, 2017; Manini, 2017). This particularly applies to literature in Serbia (Lukic, 2017a, b; 2018) - as far as we know, there is no complete work that has been published so far on the issue of the importance of measuring and analyzing gross operational margin in Serbia's trade companies (food retailers).

As a measure of long-term performance of (food) retailers, the operating profit margin has its advantages and disadvantages. It is considered that during the usage of this criterion retailers are focused on the performance of fundamental business rather than on financial decision-making related to depreciation of fixed assets, interest and financial structure (lending instead of increasing equity by selling shares) (Levy, 2019). In view of this, it provides bankers, investors, creditors, fiscal authorities and others an insight into the long-term potential options for collecting their retailers' claims.

More and more financial analysts are aware of certain problems of interpreting the EBITDA margin, and in order to overcome them, the model of economic additional value (the so-called EVA model) is recommended. Nevertheless, it should also be noted that the very model of economic value addition has its own weaknesses, which primarily relate to subjective assumptions regarding the calculation of capital costs. In conclusion, it is necessary to use both models (EBITDA margin, EVA model) concurrently when assessing the long-term performance of retailers. 
We are well aware of the fact that in recent years many global retailers, and what we consider quite right, also regularly report on the economic value added (for example, METRO group and others) in the context of integrated financial reporting. In this way, the problem of interpreting the EBITDA margin is partially mitigated. Due to the specifics of the nature itself, way of doing business and the applied financial management strategy, the dynamics of the size of the operating profit margin varies by individual types of trade (wholesale and retail), retail companies and countries in which they operate, retail chains (types of shops) and product categories. This is scientifically proven by the empirical analysis of EBITDA-size dynamics of retailers 'margin which has been carried out from different perspectives.

Model of calculating the EBITDA margin, it is determined in the following way:

EBITDA = Revenue - Expenses (excluding interest, taxes, depreciation and amortization), i.e.

EBITDA $=$ Net profit + Interest + Tax + Depreciation + Amortization.

From this last formula it follows that:

Net profit $=$ EBITDA $-($ Interest + Tax + Depreciation + Amortization $)$.

For illustration purposes Table 1 shows the model for calculating the EBITDA margin in the global retailer Wal-Mart. Therefore, it is consistent with the model shown above.

Table 1. Model of calculating the EBITDA margin at Wal-Mart (USD \$ million)

\begin{tabular}{|c|c|c|}
\hline & January 31, 2018 & January 31, 2017 \\
\hline Net income & 9,862 & 13,643 \\
\hline $\begin{array}{l}\text { Add: Net income attributable to non- } \\
\text { controlling interest } \\
\text { Less: Income from discontinued } \\
\text { operations, net of income tax } \\
\text { Add: Income tax expense }\end{array}$ & $\begin{array}{c}661 \\
\\
- \\
4,600\end{array}$ & $\begin{array}{c}- \\
6,204\end{array}$ \\
\hline Earnings before tax (EBT) & 15,123 & 20,497 \\
\hline $\begin{array}{l}\text { Add: Interest expense, debt, capital } \\
\text { lease and financing obligations }\end{array}$ & 2,330 & 2,367 \\
\hline $\begin{array}{l}\text { Earnings before interest and tax } \\
\text { (EBIT) }\end{array}$ & 17,453 & 22,864 \\
\hline Add: Depreciation and amortization & 10,529 & 10,080 \\
\hline $\begin{array}{l}\text { Earnings before interest, } \\
\text { tax, depreciation and } \\
\text { amortization(EBITDA) }\end{array}$ & 27,982 & 32,944 \\
\hline
\end{tabular}

Source: Retrieved from https: // www.stock-analysis-on.net (July 10,2018) 


\section{Results and discussion}

The value multiplier is determined as follows:

Enterprise Value $/$ EBITDA = $($ Market Value of Equity + Value of Debt-Cash $) /$ EBITDA.

It shows how the market values the (retail) firm in accordance with the ability to generate operational profits (Enterprise value/EBITDA (EV/EBITDA). As an illustration, Table 2 shows a value multiplier on the example of a food value chain in the US.

Table 2. Food value chain value multiplier in US, January 5, 2018

\begin{tabular}{|l|c|}
\hline & EV/EBITDA \\
\hline Farm/Agriculture & 13.07 \\
\hline Food processing & 13.01 \\
\hline Food wholesale & 10.43 \\
\hline Retail (grocery and food) & 8.40 \\
\hline Restaurant/Dining & 12.69 \\
\hline
\end{tabular}

Source: Enterprise Value Multiples by Sector (US), January 5, 2018, Retrieved from ,http:// pages.stern.nyu.edu/ adamodar/New Home Page/datafile/vebitda.html (July 10, 2018)

Note: Enterprise Value / EBITDA = (Market Value of Equity + Value of Debt-Cash) / EBITDA.

The data in a given table show that the value multiplier is different for some members of the food value chain in the US. Thus, for example, it is significantly higher for farming/agriculture (13.07) than for retail (8.49). This is partly due to differences in the very nature of their business. In order to make in-depth analysis of the EBITDA margins in the food retail sector, Table 3 shows a value multiplier of the Wal-Mart retailer and its competitors for 2017 and 2018.

Table 3. Value multiplier,Wal-Mart (January 31, 2017 and 2018)

\begin{tabular}{|l|c|c|c|c|c|c|}
\hline $\begin{array}{l}\text { Wal-Mart Inc., EV / } \\
\text { EBITDA calculation }\end{array}$ & $\begin{array}{c}\text { January } \\
\mathbf{3 1 , 2 0 1 8}\end{array}$ & $\begin{array}{c}\text { January } \\
\mathbf{3 1 , 2 0 1 7}\end{array}$ & $\begin{array}{c}\text { January } \\
\mathbf{3 1 ,} \\
\mathbf{2 0 1 6}\end{array}$ & $\begin{array}{c}\text { January } \\
\mathbf{3 1 , 2 0 1 5}\end{array}$ & $\begin{array}{c}\text { January } \\
\mathbf{3 1 , 2 0 1 4}\end{array}$ & $\begin{array}{c}\text { January } \\
\mathbf{3 1 2 0 1 3}\end{array}$ \\
\hline $\begin{array}{l}\text { Enterprise value (EV), } \\
\text { (USD \$ million) }\end{array}$ & 305,207 & 260,427 & 260,724 & 306,165 & 300,184 & 297,926 \\
\hline $\begin{array}{l}\text { Earnings before interest, } \\
\text { tax, depreciation } \\
\text { and amortization } \\
\text { (EBITDA), (USD \$ } \\
\text { million) }\end{array}$ & 27,982 & 32,944 & 33,640 & 36,433 & 35,861 & 36,489 \\
\hline Ratio EV/ EBITDA & 10.91 & 7.91 & 7.75 & 8.40 & 8.37 & 8.16 \\
\hline $\begin{array}{l}\text { Benchmarking EV/ } \\
\text { EBITDA competition }\end{array}$ & & & & & & \\
\hline Amazon.com Inc. & - & 43.74 & 31.40 & 33.08 & 33.45 & 41.58 \\
\hline Costco Wholesale Corp. & - & 12.63 & 13.27 & 13.49 & 12.08 & 12.30 \\
\hline eBay Inc. & - & 14.50 & 8.04 & 8.92 & 12.34 & 12.88 \\
\hline Home Depot Inc. & 13.46 & 12.90 & 13.23 & 12.90 & 11.11 & 11.74 \\
\hline Lowe's Cos.Inc. & 11.24 & 11.43 & 12.18 & 12.79 & 10.47 & 9.60 \\
\hline
\end{tabular}




\begin{tabular}{|l|c|c|c|c|c|c|}
\hline $\begin{array}{l}\text { Wal-Mart Inc., EV / } \\
\text { EBITDA calculation }\end{array}$ & $\begin{array}{c}\text { January } \\
\mathbf{3 1 , 2 0 1 8}\end{array}$ & $\begin{array}{c}\text { January } \\
\mathbf{3 1 , 2 0 1 7}\end{array}$ & $\begin{array}{c}\text { January } \\
\mathbf{3 1 ,} \\
\mathbf{2 0 1 6}\end{array}$ & $\begin{array}{c}\text { January } \\
\mathbf{3 1 , 2 0 1 5}\end{array}$ & $\begin{array}{c}\text { January } \\
\mathbf{3 1 , 2 0 1 4}\end{array}$ & $\begin{array}{c}\text { January } \\
\mathbf{3 1 , 2 0 1 3}\end{array}$ \\
\hline Netflix Inc. & - & 18.03 & 11.80 & 10.59 & 8.22 & 9.62 \\
\hline Target Corp. & 6.96 & 5.59 & 7.47 & 9.21 & 7.85 & 8.09 \\
\hline TJX Cos.Inc. & - & 11.16 & 11.83 & 11.14 & 10.70 & 9.10 \\
\hline EV / EBITDA, Sector & & & & & & \\
\hline General retailers & - & 15.92 & 12.72 & 12.34 & 10.93 & 10.95 \\
\hline EV / EBITDA, Industry & & & & & & \\
\hline Customer service & - & 12.26 & 11.49 & 10.91 & 10.77 & 10.30 \\
\hline
\end{tabular}

Source: Retrieved from https: // www.stock-analysis-on.net (July 28, 2018)

The data in the given table show that the value multiplier differs between some food retailers. Thus, for example, on January 31, 2018, in Target Corp. it was 6.96 and in WalMart 10.91, respectively. The Wal-Mart value multiplier is lower than the average of the sector and industry. These differences are certainly the result of the implementation of different financial management strategies (lending versus the increase in equity by selling shares). Earnings before interest, taxes, depreciation and amortization differ among individual food retail companies. Table 4 illustrates the dynamics of the EBITDA margin of the global retailer Wal-Mart for the period 2008 - 2017.

Table 4. Dynamics of EBITDA margin of Wal-Mart, 2008 - 2017

\begin{tabular}{|l|c|}
\hline \multicolumn{1}{|c|}{ End of period } & WMT \\
\hline January 2008 & NA \\
\hline January 2009 & $7.3 \%$ \\
\hline January 2010 & $7.6 \%$ \\
\hline January 2011 & $7.9 \%$ \\
\hline January 2012 & $7.7 \%$ \\
\hline January 2013 & $7.7 \%$ \\
\hline January 2014 & $7.5 \%$ \\
\hline January 2015 & $7.5 \%$ \\
\hline January 2016 & $7.0 \%$ \\
\hline October 2016 & $6.8 \%$ \\
\hline January 2017 & $6.8 \%$ \\
\hline October 2017 & $6.6 \%$ \\
\hline
\end{tabular}

Source: Retrieved from https://finbox.io/WMT/explorer/ebitda_margin (July 10,2018)

Recently, the EBITDA margin has decreased in Wal-Mart compared to the previous period. Compared to some competitors it is larger and compared to others - smaller (for example, Target Corporation 9.9\%) (Table 5). This is, partly, the result of the very nature of the industry operations of its own, sector, company size and business operations model (i.e. the applied financial strategy of the business). 
Table 5. EBITDA margin of Wal-Mart and its competitors, 2017

\begin{tabular}{|l|c|}
\hline \multicolumn{1}{|c|}{ Company } & EBITDA margin \\
\hline Spartan Nash Company (SPTN) & $-0.3 \%$ \\
\hline Smart \& Final Stores, Inc. (SFS) & $3.1 \%$ \\
\hline Kroger Company (The) (KR) & $4.5 \%$ \\
\hline CompanhiaBrasileira de Distribuicao (CBD) & $6.1 \%$ \\
\hline Casey's General Stores, Inc. (CASY) & $6.2 \%$ \\
\hline Best Buy Co., Inc. (BBY) & $6.2 \%$ \\
\hline CVS Health Corporation (CVS) & $6.6 \%$ \\
\hline Wal-Mart Stores, Inc. (WMT) & $6.6 \%$ \\
\hline Target Corporation (TGT) & $9.9 \%$ \\
\hline Consumer Staples (SECTOR:STPL) & $12.5 \%$ \\
\hline Procter \& Gamble Company (The) (PG) & $25.6 \%$ \\
\hline \#ERROR! (CNCO) & $\mathrm{NA}$ \\
\hline
\end{tabular}

Source: Retrieved from https://finbox.io/WMT/explorer/ebitda_margin (July 11, 2018)

Table 6 shows the dynamics of EBITDA margin of Tesco for the period 2014 - 2018.

Table 6. EBITDA margin of Tesco, 2014 - 2018

\begin{tabular}{|l|c|c|c|c|c|}
\hline $\begin{array}{c}\text { Fiscal year March-February. All values } \\
\text { are expressed in millions of pounds (GBP) }\end{array}$ & $\mathbf{2 0 1 8}$ & $\mathbf{2 0 1 7}$ & $\mathbf{2 0 1 6}$ & $\mathbf{2 0 1 5}$ & $\mathbf{2 0 1 4}$ \\
\hline Sales/Revenue & 57,491 & 55,917 & 53,933 & 56,925 & 63,557 \\
\hline EBITDA & 2,957 & 2,581 & 2,202 & $(1,733)$ & 4,757 \\
\hline EBITDA growth & $14.57 \%$ & $17.21 \%$ & $227.06 \%$ & $-136.43 \%$ & - \\
\hline EBITDA margin & $5.14 \%$ & - & - & - & - \\
\hline EBIT & 1.663 & 1.284 & - & - & 3.225 \\
\hline
\end{tabular}

Source: Retrieved from https:/quotes.wsj.com/UK/XLON/TSCO/financials/annual/incomestatement (July 11, 2018)

The data in the given table show that the share of EBITDA margin in revenues is lower in Tesco $(5.14 \%)$ than in Wal-Mart $(6.6 \%)$. This is partly a consequence of a different model of doing financial operations. Table 7 shows the EBITDA margin of Ahold Delhaize, which operates in Serbia as Delhaize Serbia.

Table 7. EBITDA margin of Ahold Delhaize

\begin{tabular}{|l|c|c|c|c|}
\hline & $\mathbf{1 2 / 1 6 A}$ & $\mathbf{1 2 / 1 7 E}$ & $\mathbf{1 2 / 1 8 E}$ & $\mathbf{1 2 / 1 9 E}$ \\
\hline Revenue $(€$ million) & 63,093 & 63,943 & 65,348 & 66,920 \\
\hline EBITDA $(€$ million) & 4,142 & 4,267 & 4,507 & 4,836 \\
\hline EBIT $(€$ million) & 2,420 & 2,386 & 2,638 & 2,923 \\
\hline EBIT growth $(\%)$ & 7.9 & $(1.4)$ & 10.6 & 10.8 \\
\hline EBITDA margin $(\%)$ & 6.6 & 6.7 & 6.9 & 7.2 \\
\hline EBIT margin $(\%)$ & 3.8 & 3.7 & 4.0 & 4.4 \\
\hline EV/EBITDA $(x)$ & 6.7 & 6.4 & 6.0 & 5.5 \\
\hline EV/EBIT $(x)$ & 11.4 & 11.4 & 10.3 & 9.2 \\
\hline
\end{tabular}

Source: Retrieved from https://research-doc.credit-suisse.com/docView?language=ENG\&for $\underline{\text { mat }=P D F \& \text { sourceid }=\text { emgpm\&document } \mathrm{id}=1077229781 \& \text { serialid }=7 \% 2 \mathrm{~F} \% 2 \mathrm{FS} 91 \mathrm{dDW} 4 \mathrm{ewId}}$ MX6A26zlMtYs6VxLxiTmpgD2zQdGM\%3D (July 22, 2018) 
In Ahold Delhaize, the EBITDA margin is higher than at Tesco $(5.14 \%)$ and is approximately the same as with Wal-Mart (6.6\%). In the future, there is an estimated growing trend. The EBITDA margin is certainly different among observed countries in which Ahold Delhaize operates. Ahold Delhaize's operating profit margin, observed by individual countries in which it operates, is significantly higher in the US and the Netherlands than in Belgium and Central and Southeastern Europe (to which the Delhaize Serbia belongs). These differences are the result of different general business conditions and applied (financial) business strategies. Table 8 shows the EBITDA margin of the Russian company X5 Retail Group for the period 2012-2016.

Table 8. Dynamics of EBITDA margin of the company X5 Retail Group, 2012-2016

\begin{tabular}{|l|c|c|}
\hline & EBITDA Margin (Rub bn) & EBITDA margin, \% \\
\hline 2012 & 35,1 & $7.1 \%$ \\
\hline 2013 & 38,4 & $7.2 \%$ \\
\hline 2014 & 46,4 & $7.3 \%$ \\
\hline 2015 & 59,4 & $7.3 \%$ \\
\hline 2016 & 79,5 & $7.7 \%$ \\
\hline $2016 / 2015$ & $33.8 \%$ & \\
\hline
\end{tabular}

Source: Q1 2017 Financial Results, X5 Retail Group, Moscow, Russian Federation 27 March 2017, Retrieved from https:/www.x5.ru/en/Documents/X5-Q1-2017-Financial-results.pdf (July 12, 2018)

The data in the given table clearly show that the EBITDA margin of the company X5 Retail Group is higher than in Wal-Mart, Tesco and Ahold Delhaize. In other words, its profitability measured by cash flows from operations (using EBITDA margin) is slightly better than the observed retail companies.

In order to make anin-depth analysis of long-term trade performance in Serbia measured by the EBITDA margin, we will show the respective margin for three significant (food retail) trade companies in Serbia for 2016 (Table 9). Based on the data presented in the given table, we can also conclude that the EBITDA margin of the leading (food) trading companies in Serbia is lower than the analyzed comparable (food retail) trade companies from the developed market economies.

Table 9. EBITDA margin of significant trade companies in Serbia, 2016

\begin{tabular}{|l|c|c|}
\hline & EBITDA margin, (million dinars) & EBITDA margin, (\% from sales) \\
\hline Ahold Delhaize Serbia & 3,719 & $4.3 \%$ \\
\hline Mercator-S & 3,081 & $2.9 \%$ \\
\hline IDEA & 117 & $3.99 \%$ \\
\hline
\end{tabular}

Source: Author's calculation based on data of Business Registers Agency, Belgrade.

In order to make a more complex analysis of the issues discussed in this paper, we will look at the dynamics of interest costs of Delhaize Serbia and Mercator-S. These two companies are the most important retailers in Serbia (according to the realized business revenues in 2017). Table 10 shows the dynamics of interest costs of Delhaize 
Serbia and Mercator-S, and some global retail chains for the purpose of international comparisons.

Table 10. Interest costs of selected retailers in Serbia

\begin{tabular}{|c|c|c|c|c|c|c|c|c|c|c|}
\hline & \multicolumn{5}{|c|}{ Delhaize Serbia } & \multicolumn{5}{|c|}{ Mercator-S } \\
\hline & $\begin{array}{c}\text { Revenues } \\
\text { (million } \\
\text { dinars) }\end{array}$ & $\begin{array}{c}\text { Interest } \\
\text { cost } \\
\text { (million } \\
\text { dinars) }\end{array}$ & $\begin{array}{c}\text { Interest } \\
\text { costs (\% } \\
\text { of rev- } \\
\text { enues)* }\end{array}$ & $\begin{array}{c}\text { Interest } \\
\text { rev- } \\
\text { enues } \\
\text { (million } \\
\text { dinars) }\end{array}$ & \begin{tabular}{|c|} 
Net \\
interest \\
costs \\
(mil- \\
lion \\
dinars)
\end{tabular} & $\begin{array}{c}\text { Rev- } \\
\text { enues } \\
\text { (million } \\
\text { dinars) }\end{array}$ & $\begin{array}{c}\text { Interest } \\
\text { costs } \\
\text { (million } \\
\text { dinars) }\end{array}$ & $\begin{array}{c}\text { Interest } \\
\text { costs }(\% \\
\text { revenues)* }\end{array}$ & $\begin{array}{c}\text { Interest } \\
\text { revenues } \\
\text { (million } \\
\text { dinars) }\end{array}$ & $\begin{array}{c}\text { Net } \\
\text { interest } \\
\text { costs } \\
\text { (million } \\
\text { dinars) }\end{array}$ \\
\hline 2014 & 74,943 & 13 & 0.02 & 179 & 166 & 72,554 & 555 & 0.76 & 68 & 487 \\
\hline 2015 & 77,383 & 11 & 0.01 & 239 & 228 & 112,229 & 975 & 0.87 & 83 & 892 \\
\hline 2016 & 85,025 & 1 & 0.00 & 215 & 214 & 100,042 & 1.247 & 1.24 & 64 & 1,183 \\
\hline 2017 & 94,884 & 1 & 0.00 & 410 & 409 & 90,747 & 1.314 & 1.45 & 12 & 1,302 \\
\hline $\begin{array}{c}\text { Global } \\
\text { retailers }\end{array}$ & & & 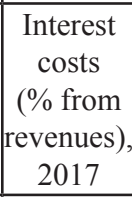 & & & & & & & \\
\hline $\begin{array}{l}\text { Wal-Mart } \\
\text { Q4 } 2017\end{array}$ & & & 0.47 & & & & & & & \\
\hline $\begin{array}{c}\text { Target Q4 } \\
2017 \\
\end{array}$ & & & 0.92 & & & & & & & \\
\hline $\begin{array}{c}\text { Kroger } \\
\text { Co. Q4 } \\
2017 \\
\end{array}$ & & & 0.49 & & & & & & & \\
\hline Tesco & & & 1.56 & & & & & & & \\
\hline Carrefour & & & 0.40 & & & & & & & \\
\hline $\begin{array}{c}\text { Ahold } \\
\text { Delhaize } \\
\end{array}$ & & & 0.46 & & & & & & & \\
\hline $\begin{array}{c}\text { X5 Retail } \\
\text { Group }\end{array}$ & & & 1.16 & & & & & & & \\
\hline
\end{tabular}

Source: Business Registers Agency of the Republic of Serbia, CSIMarket, Retrieved from https://csimarket.com/ (December 14, 2018), and Annual Report Tesco 2017, Annual Report Carrefour 2017, Annual Report Ahold Delhaize 2017, X5 Retail Group Annual Report 2017, Retrieved from https://ar2017.x5.ru/en (December 24, 2018)

Note: *Calculation performed by the author(s)

The data in the given table show that the interest costs in Delhaize Serbia decreased in the observed period, and increased with Mercator-S from year to year. In 2017, interest costs in percentages of revenues are higher in the company Mercator-S, and lower in Delhaize Serbia in comparison to the observed global retail chains (Wal-Mart, Target, Kroger Co.).

Table 11 shows the interest coverage ratio of selected retailers in Serbia in 2017. 
Table 11. Interest coverage ratio of selected retailers in Serbia, 2017

\begin{tabular}{|c|c|c|c|c|c|}
\hline & $\begin{array}{l}\text { Net profit } \\
\text { (million } \\
\text { dinars) }\end{array}$ & $\begin{array}{l}\text { Interest } \\
\text { (million } \\
\text { dinars) }\end{array}$ & $\begin{array}{l}\text { Tax (million } \\
\text { dinars) }\end{array}$ & $\begin{array}{c}\text { Earnings before } \\
\text { interest and tax } \\
\text { (EBIT) (million } \\
\text { dinars)* }\end{array}$ & $\begin{array}{c}\text { Interest coverage } \\
\text { ratio (Earnings } \\
\text { before interest } \\
\text { and tax / } \\
\text { Interest)* }\end{array}$ \\
\hline Delhaize Serbia & 4,264 & 1 & 237 & 4,502 & 4.502 \\
\hline Mercator-S & $(6,851)$ & 1,314 & 144 & $(5,393)$ & $(4.10)$ \\
\hline \multicolumn{6}{|l|}{ Global retailers } \\
\hline Wal-Mart & & & & & 9.08 \\
\hline Target & & & & & 13.74 \\
\hline Kroger Co. & & & & & 10.99 \\
\hline X5 Retail Group & & & & & 3.77 \\
\hline
\end{tabular}

Source: Business Registers Agency of the Republic of Serbia, CSIMarket, Retrieved from https://csimarket.com/ (December 14, 2018) and X5 Retail Group Annual Report 2017, Retrieved from https://ar2017.x5.ru/en (December 24, 2018)

Note: *Calculation performed by the author(s)

The data in the given table show that the interest coverage ratio of selected retailers in Serbia is lower compared to the observed global retailers. This is, among other things, the result of more unfavorable general conditions of business in Serbia. In addition to the unfavorable financial structure, we need to add that there is also a lower level of implementation of modern concepts of business as well as modern technology in the retail market of Serbia.

More recently, in addition to the standard indicators, non-standard performance indicators such as operating margin (EBITDA) have been increasingly analyzed in all companies. In this way, as the results of the research in this paper on the example of global food retailers and in Serbia show, the financial performance is realized.

Due to the importance of food retailers, therefore, in the future, they should pay increasing attention to the operating margin indicator in order to improve the efficiency of financial performance management. This is especially true for food retailers in Serbia. Overall, it is recommended that food retailers in Serbia increasingly measure their performance using the operating maze indicator as presented in this paper.

\section{Conclusions}

For trade companies in Serbia, there is a tendency of reducing interest costs. This was influenced by numerous factors, among other things, by reducing the banking interest rate, a stable exchange rate and improving general business conditions.

According to the realized business income in 2017 in Serbia, the two most important retailers are Delhaize Serbia and Mercator-S. The general conclusion is that their interest coverage ratio is lower than with the global retailers such as Wal-Mart, Target and Kroger Co. This is due to the fact that there are unfavorable structures of the capital of the observed retailers in Serbia. 
The EBITDA margin of the analyzed leading trading companies in Serbia (Ahold Delhaize Serbia, Mercator-S and IDEA) is lower than that of analyzed comparable retail (primarily food) trade companies from the developed market economies. Overall, more efficient management of the financial structure of capital, sales revenues, costs of goods sold (including operating costs, interest) and profit can significantly influence the increase in the EBITDA margin as a measure of the long-term performance of trading companies in Serbia. This will definitely have a positive impact on the dynamics of the size and efficiency of investments, as a key factor in the performance of trade companies in Serbia.

There is a tendency of increasing interest coverage ratio in trading companies in Serbia. It is slightly higher than a defined comparable industry standard. In view of this, the solvency of trading companies in Serbia is increasing.

\section{Conflict of interests}

The authors declare no conflict of interest.

\section{References}

1. Annual Report Tesco 2017.

2. Annual Report Carrefour 2017.

3. Annual Report Ahold Delhaize 2017.

4. Berman.B. and Evans. J. R. and Patroli, M. C. (2018). Retail Management Boston: Prentice Hall.

5. Calva, A. (2017). Case of financial ratio analysis: Food retail industry in Canada (2012 2016).Acus Consulting Ltd., 1-13, Retrieved from www.AcusConsulting.com (July 31, 2018).

6. Carstea, G., Corbos, R.A., Popescu, R.I. and Bunea, O.I. (2017). Analysis of the influence of some indicators on the profitability of the FMCG retail market in Romania. Proceedings of the $11^{\text {th }}$ International Management Conference ,The Role of Management in the Economic Paradigm of the XXI Century ", November $2^{\text {nd }}-4^{\text {th }}$, Bucharest, Romania, 481-492.

7. CSIMarket, Retrieved from https://csimarket.com/ (December 14, 2018).

8. Corona, R. (2014) .Comparative Analysis of Major US Retailers Based on Enterprise Marketing Efficiency. Global Business research, 8(4), 25-39.

9. Enterprise Value Multiples by Sector (US), January 5, 2018, Retrieved from ,http://pages.stern.nyu.edu/ adamodar/New_Home_Page/datafile/vebitda.html (July 10, 2018) .

10. Hoe, L.W., Siew; L.W., Wai, C.J. (2017). AStudy on the Performance of the Retailers in Malaysia with TOPSUS Model. International Journal of Economic Theory and Application, 5(1), 7-12.

11. Ko, K., Chang, M., Bae, E.S. and Kim, D. (2017). Efficiency Analysis of Retail Chain Stores in Korea. Sustainability, 9(9), 16-29, Retrieved from https://doi. org/10.3390/su9091629 (July 31,2018). 
12. Kenchington, D., Wan,C. and Yüksel, H.Z.(2019). Gross profitability and mutual fund performance. Journal of Banking \& Finance, 104, 31-49.

13. Lambrinoudakis, C., Skiadopoulos,G. and Gkionis, K. (2019). Capital structure and financial flexibility: Expections of future shocks. Journal of Banking \& Finance, 104, 1-18.

14. Lekić,N., Savić,G., Knežević, S. and Mitrović, A. (2018). The Efficiency analysis in small wineries in the Republic of Serbia. Economics of Agriculture, 65(4), 1529-1544.

15. Levy, M. Weitz. B. A. and Grewal. D.(2019).Retailing Management. New York: McGraw-Hill.

16. Lukic, R. (2011). Estimates of economic performance of organic food retail trade. Economic research, 24(3), 157-169.

17. Lukic, R. (2017a). The Impact of Margin on the Performance of Trade Companies in Serbia. LIMES plus: Journal of Social Sciences and Humanities, 3, 49-71.

18. Lukic, R. and Sokic, M. (2017b). Efficiency Analysis of Trade Capital Management in Serbia. Management Research and Practice, 9( 4), 38-47.

19. Lukic, R. (2018). The Analysis of the Operative Profit Margin of Trade Companies in Serbia. Review of International Comparative Management , 19(5), 458-478.

20. Lukić, R., Lalić, S., Sućeska, A., Hanić, A. and Bugarčić, M. (2018). Carbon diohide emissions in retail food. Economics of Agriculture, 65(2), 859-874.

21. Manini, R. and Amat, O. (2017) .Credit Scoring for the Supermarket and Retailing Industry: Analysis and Application Proposal. European Accounting and Management Review, 4(1), 75-88.

22. Popović, S, Janković, I, \& Stojanović, Ž., (2018). The importance of bank credits for agricultural financing in Serbia. Economics of Agriculture, 65 (1), 65-80.

23. Shamshur, A. and Weile, L. (2019). Does bank efficiency influence the cost of credit? Journal of Banking \& Finance, 105, 62-73.

24. Q1 2017 Financial Results, X5 Retail Group, Moscow, Russian Federation 27 March 2017, Retrieved from https:/www.x5.ru/en/Documents/X5-Q1-2017-Financial-results.pdf(July 12, 2018).

25. Sui, Y. (2017) .The Research on the Applications and Limitations of EBITDA. $20172^{\text {nd }}$ International Conference on Sustainable Energy and Environment Protection (ICSEEP 2017), 66-69.

26. Špička, J. (2016) .Market Concentration and Profitability of the Grocery Retailers in Central Europe. Central European Business Review, 5(3), 5-24.

27. Tan, Z. (2016) .Application of Discounted Cash Flow Model Valuation - Wal-Mart. MPRA Paper No. 83903, 1-16, Retrieved from https://mpra.ub.uni-muenchen. de/83903/1/MPRA paper 83903.pdf (July 31, 2018).

28. Tao,C., Rong,G.J., Kamiya,S. and Pingyi, L.(2019). Marginal cost of risk-based capital and risk-taking. Journal of Banking \& Finance, 103, 130-145.

29. X5 Retail Group Annual Report 2017, Retrieved from https://ar2017.x5.ru/en (December 24, 2018).

30. Ye,J., Zhang, A. and Dong, Y. (2019). Banking reform and industry structure: Evidence from China. Journal of Banking \& Finance, 104, 70-84. 